\title{
CEACAM6 Gene
}

National Cancer Institute

\section{Source}

National Cancer Institute. CEACAM6 Gene. NCI Thesaurus. Code C107469.

This gene plays a probable role in both cell-cell signaling and cell adhesion. 